\title{
SOCIAL INVESTMENT RISKS? AN EXPLORATIVE ANALYSIS OF NEW SOCIAL RISKS IN THE SOCIAL INVESTMENT STATE
}

\author{
Luc Benda - Menno Fenger - Ferry Koster - Romke Van der Veen ${ }^{l}$
}

\begin{abstract}
Individual responsibilities and individual capabilities are becoming increasingly important in public policies of European welfare states. Therefore, it is said that European welfare states are developing in the direction of social investment states. In this article we argue that the shift towards the social investment state may lead to new social risks and new inequalities. Building upon Bonoli's (2005) seminal article, we introduce the concept of 'social investment risks' to refer to these risks. In this article we explore and identify the development towards a social investment state in detail by focusing on different social policy trends in different welfare areas and by analyzing their impact on the individual level. We deconstruct the underlying assumptions of the social investment paradigm and reflect on the role of individual capabilities and social capital in the social investment state. We assess to what extent the distribution of these capabilities creates new social risks and new inequalities using examples from the Netherlands. Dealing with these new inequalities and new social risks may be considered new challenges for welfare states. Therefore, this article innovatively expands the borders of currentday welfare state research and explores the consequences of the social investment paradigm.
\end{abstract}

KEYWORDS: New social risks; Welfare State Regimes; Capabilities; Social Capital; Social Investment; Legitimacy; Motivation; Crowding in, crowding out

1 The authors are affiliated with Erasmus University, Rotterdam; e-mail: fenger@essb.eur.nl 


\section{INTRODUCTION}

Since 1973 European welfare states have been undergoing a continuous process of adjustment to fiscal austerity and new social, political and economic conditions. The readjustment of the post-war welfare state first led to processes of political and economic reform in most welfare states (see Pierson, 1994; compare Castles, 2004). In time, the politics of retrenchment dominant in the 1970s and 1980s gave way to the politics of institutional change (cf. Streeck \& Thelen, 2005; Mahoney \& Thelen, 2010; Pierson, 1994). The division of responsibilities between the state, citizens, firms, interest groups and the socalled third sector in the policies of the welfare state changed. This led to a transformation of social policies: an increase in the individual responsibility of actors (citizens, employees, firms, professionals, etc.) under the umbrella of - and not instead of - state-organized social policies. This process has been characterized as a transition towards a social investment state: a welfare state in which social policies are mainly oriented towards and also legitimized by investment in human capital. Traditional welfare states aimed at providing compensation for the occurrence of traditional social risks like old age, disability and unemployment. The social investment state is aimed at preventing these risks by educating citizens and enhancing individual capabilities to build resilience. The transformation from traditional welfare states into social investment states involves institutional readjustments. One of the most significant changes is related to the issue of scale: the division of authorities between national, regional and local government. Administrative and governmental responsibilities are decentralized to local or sectorial authorities or centralized with supra-national authorities (Kazepov, 2010). This also entails an increasing emphasis on civil society as a distributor of welfare. This fits within the discourse of the big society which sees citizens as 'autonomous, self-reliant and democratically engaged individuals working for common purpose' (Bone, 2012: 11).

We argue that, because of these processes, the capabilities and social capital of individuals are becoming central determinants within the welfare system. As a result, new divisions are created which may present new social risks and new inequalities. This article aims to explore these new social risks and new inequalities that may be caused by the transition towards a social investment state. In doing so, the article contributes to an emerging body of literature on the shift towards a social investment state (see Taylor-Gooby, 2013; Hemerijck, 2012; Ellison and Fenger, 2013). We develop a theoretically based typology of social investment risks which makes policy officials and social policy scholars more sensitive to the potential pathological policy consequences of the social investment state. 
This article is structured as follows: In the next section, we elaborate on the background of the social investment state. In Section 3 we move on to a discussion of the new social risks as they have been identified by Bonoli (2005). In Section 4 we reflect on the underlying assumptions of the social investment paradigm. Section 5 forms the core of this article: there we present an overview of social risks in the social investment state. In the final section we reflect on the meaning of these social investment risks for practical policy making and research of the social investment paradigm.

\section{TOWARDS SOCIAL INVESTMENT?}

The welfare states that were developed in the first decades of the twentieth century and matured in in the early post-war decades were intended to protect citizens from traditional social risks like unemployment, poverty, and illness. However, the measures that were implemented - health insurance, unemployment insurance and social assistance - focus on repairing 'damage' after it happens. Social investment policy, in contrast, aims to prepare instead of repair individuals in relation to the labor market (Giddens, 1998). The social investment state aims to increase social inclusion and minimize the intergenerational cycle of poverty in order to protect individuals from the increasing insecurity (flexibilization) of the labor market. It aims to do so in a manner which does not undermine individual responsibility for one's own personal well-being, and in a way that helps the system cope with changing demographics like an aging population and the detraditionalization of the family (Jenson, 2012: 61-7). Three principles are central to the social investment perspective. The first is based on the equality of opportunity, and thereby follows the liberal notion of equality. By creating equal opportunities through investment the intergenerational cycle of poverty should be broken. Therefore, the social investment paradigm highlights the importance of education and the prominent position it has in the lives of all. Early childhood education and life-long learning are, besides formal education, the main routes to social security and a way to overcome new inequalities based on technology and skills.

The second principle rests on the premise that promoting social inclusion by investing in individuals and thereby expanding active and civil society is beneficial to the collective good (Jenson \& Saint Martin, 2006). Hence, the development of human capital and labor market mobility are the main concepts of the social investment perspective (Taylor-Gooby, 2008). This requires an 'empowering' or 'active' state which focuses on partnerships with non-profit and private market parties and 'restructures', 'redesigns' or 'recasts' the welfare 
state (Morel, Palier \& Palme, 2012: 1-19). According to this perspective, the state provides opportunities for individual citizens, but it is the responsibility of citizens to use these opportunities. For instance, Jenson and St. Martin (2003) highlight the active role that is required of citizens in the social investment paradigm. The state in the social investment paradigm is an enabling state with active and responsible citizens.

Recent trends indicate that many European welfare states increasingly show characteristics of social investment states. The development of more individualized social services, personalized around the needs of the individual (Gerven \& Ossewaarde, 2012: 49), demands a new and complex system of administration (Pfeifer, 2009: 118). Social policies have to deal with the individualization of social risks and the fact that personal risk biographies are being formed by the choices individuals make (Giddens, in Gerven \& Ossewaarde, 2012: 39). The distributive effects of these new services are dependent on the distribution of formal welfare (collectively organized) and on the access citizens have to informal welfare (social support). Access to formal and informal welfare is dependent on the (bureaucratic and social) capabilities of individuals, and capabilities to acquire and manage formal and informal welfare differ.

However, whether this social investment strategy is actually being implemented and in what scope is still under debate. "In most countries the investment in knowledge and employment mobility enhancing benefits that are distinctive parts of the new approach are not being effectively pursued." (TaylorGooby, 2008: 18). It may be that the social investment approach is only used as a rhetorical strategy to disguise a continuing politics of retrenchment (TaylorGooby \& Stoker, 2011; Wiggan, 2012). One may ask whether this phenomenon results from liberal ideology, the promotion of free-market capitalism and personal freedom (Friedman, 1982), or from the development of social investment. Individual responsibility figures prominently in both discourses. The possibility exists that after years of convergence towards a European model of welfare distribution (the trend to Europeanization of the welfare state model) two discourses have emerged: one of neoliberalism and the other of social investment. However, both discourses emphasize individual responsibility.

\section{NEW SOCIAL RISKS}

In his influential article 'The politics of the new social policies', Bonoli (2005) argued that due to socioeconomic transformations new social risks have evolved in addition to the traditional social risks that were introduced earlier, like old age, 
sickness, disability and unemployment. Due to the tertiarization of employment and the massive entry of women into the labor market, different risk profiles have emerged in post-industrial societies. Industrial workers traditionally had the highest risk profiles, but because of the homogeneity of the labor class and of family structures, these risks were easy to target. They also had strong political mobilization capacities to ensure improvement of their living standards. In the post-industrial society, these risk profiles have, however, changed. Because of individualization and de-traditionalization more social diversity exists within classes and families, making it harder to effectively target social risks through standardized policy measures. Due to what Bonoli describes as new social risks, welfare states have transformed and tried to adapt (Bonoli, 2005). But what are these new social risks and whom do they affect?

Bonoli (Ibid: 433-5) describes five new social risks that are related to the post-industrial society. The first new social risk he describes is the 'reconciliation of work and family life'. Because of the changed division of domestic and childcare work within the family, these activities are now being externalized, with the state and the market as the main suppliers. Problems arise when they cannot be adequately supplied and family members need to reduce working hours in order to cope. This results in great losses of welfare. This risk is even higher for 'single parent families', the second new social risk. Bonoli considers having a frail relative to also be a new social risk. Because of the changed work patterns of women, care for the frail elderly or disabled is also externalized. This task was usually performed by nonemployed women. When services are not able to provide adequate care, people are made responsible for caring for their frail relatives, which also may result in losses of welfare. These new social risks are all related to the family situation of an individual. The fourth new social risk Bonoli distinguishes is 'the possession of low or absolute skills'. Unlike in the post-war period when low-skilled workers were employed in the manufacturing industry, lowskilled workers nowadays are mostly employed in low value-added services, like cleaning, hospitality, retail-sales and the like, or they are unemployed. Job creation is limited in these sectors and people work most of the time for minimum wage or a poverty wage. Thus, having low skills or no skills at all entails a very high risk of the loss of welfare. The final new social risk according to Bonoli is having insufficient social security coverage. Because changing labor market career profiles and social security schemes are still based on the traditional career profile of the full-time employed male, having an a-typical career profile results in incomplete social security coverage and a loss of welfare. Young people, women and the low-skilled are mostly exposed to these new social risks. 
These new social risks occur because the traditional welfare states, which are geared towards compensating and decommodification, have not been fully adapted to the reality of post-industrial societies. The social investment paradigm, as discussed in the second section of this article, might be considered an adjustment of traditional welfare regimes to the post-industrial era in which individual characteristics and behavior are considered more important determinants of social risk than structural economic or social conditions. So the social investment paradigm may be considered a response to Bonoli's new social risks. However, as we claim in this article, introducing a social investment strategy in its place may result in other types of social risks. In this article we label these risks social investment risks.

\section{CAPABILITIES, SOCIAL CAPITAL AND INEQUALITIES}

In this section we will consider the social investment paradigm from a capabilities perspective. The social investment state builds upon existing capabilities of citizens and tries to improve these capabilities if needed. By focusing on capabilities we avoid an overly simplistic analysis of the distribution of welfare that focuses on just the means or the ability that individuals have to acquire wellbeing through their participation in the labor market (the human capital approach). We perceive the concept of capability as "the opportunity to achieve valuable combinations of human functionings - what a person is able to do or be" (Sen, 2005: 153). It therefore goes beyond the concept of human capital because it also incorporates social development instead of just economic development (Sen, 1997). The capabilities someone possesses are not only personal traits or the result of someone's personal network, but also the result of institutional influences. For example, the degree of universalism of the educational system determines to a large extent the chances available to citizens to obtain and expand capabilities. Therefore welfare reforms will have different effects in different welfare state regimes for different categories of citizens. Differences in the distribution of social protection by the welfare state have always existed, but the growing importance of the capabilities of actors may increase these differences (Leschke \& Jespen, 2012).

When social policies are individualized and personalized and social policy emphasis shifts to civil society, not only personal capabilities but also social capital becomes more important. We define social capital in the same way as Putnam (2001: 19): 'social capital refers to connections among individuals social networks and the norms of reciprocity and trustworthiness that arise 
from them'. In the theoretical discussion several kinds of social capital are defined. Two of the most prominent sub-concepts are bonding and bridging social capital. Bonding social capital refers to strong network ties and is usually located within families, groups of close friends and tightly structured religious, political or ethnic groups. This kind of social capital produces social support and social control but is inclusive for group members only. A perverse side effect is that it can create too much social pressure on group members with pathological consequences (for instance, see Durkheim, 2013 [1897]). Bridging social capital refers to weak social ties. These kinds of social ties let individuals bridge greater social distance than bonding ties do. Especially when it comes to information gathering and sharing, bridging social capital is of greater worth (Kääriäinen \& Lehtonen, 2006:29-30). Granovetter (1973) calls this 'the strength of weak ties'. These different types of social capital may have different values in the accumulation of welfare, depending on the type of support that is needed. When asking for health care, bonding social capital is probably of greater worth than bridging social capital, and vice versa when it comes to seeking a job outside the formal job market. The distribution of welfare then is not only the result of formal welfare arrangements but also of the access citizens have to informal welfare, which is highly dependent on their social capital. This raises the question how welfare state policies interact with the social capital of individuals. Traditionally, welfare state policies are supposed to 'crowd out' social capital, which means that informal social relations are taken over by formal (collectively organized) forms of support (Putnam, 2000). Evidence supporting this claim is not always straightforward and is sometimes even contradictory (Oorschot and Arts, 2005:21-22). However, differences appear to exist between different forms of social policy and its effect on social capital. It is possible that welfare state policy can both diminish and promote social capital (Frey and Jegen, 2001; Kääriäinen and Lehtonen, 2006; Grootegoed and van Dijk, 2012). In addition to the possession of social capital, there is also an issue related to the use of social capital. According to Elchardus and Pelleriaux (2001), the implementation of active policy has cultural effects that go beyond the desired economic effects. Due to the changing notion of personal responsibility, labor is seen as the first and foremost way to take responsibility, not only in terms of taking care of others but also taking care of oneself. One can hypothesize that this changed notion of individual responsibility also affects the way individuals judge themselves in times of need. People may blame themselves more frequently, instead of blaming others for their miseries. Consequently, they will ask for less (or no) help from others because they consider that they themselves are to blame, and are thus not entitled to receive care or assistance, or to a lesser degree. 
The increasing emphasis on human capabilities and individual responsibilities can also have a perverse effect. First, it increases the predictability and the visibility of those who are dependent on welfare state support. According to Elchardus, Marx and Pelleriaux (2003) this can undermine the legitimacy of the welfare state because social cleavages, for example between the higher and lower educated, or between different ethnic groups, become more visible and intensify. When individual responsibility and capabilities are a central variable in the social rights of citizens and in the workings of social policies it is possible that this will stimulate feelings of deprivation and exclusion among those dependent on the welfare state. By emphasizing merit and by employing a philosophy of equal chance the discontent among the lower classes in general will be heightened.

The social investment state is based on the equality of opportunities, upward social mobility and individual responsibility through investment-type policies that promote more equality within society. However, the notion of investment also involves the notion of revenue. The greatest benefits will be reaped by investing in the middle of the distribution. Reasoned from an economic perspective, focusing investment on the lower classes will not be cost-effective, but focusing on the middle classes will, thereby making the social investment state a vehicle of inequality (Taylor-Gooby, 2013: 65-71). The social investment state is also more service-orientated than its predecessors. In-kind services are less effective at reaching the lower classes than in-cash benefits. Due to this shift from offering benefits in cash to giving services-in-kind the re-distributive capacity of the welfare system is less effective from an egalitarian point of view (Esping-Andersen and Myles, 2009: 653-5).

Pintelon et al (2013) argue that social stratification based on social class still persists in the occurrence of social risks. The social risks of ill-health, unemployment, living in a jobless-household and performing low-wage work are still more prominent in the lower classes despite the implementation of social investment strategies. Pintelon et al. argue that the use of labor-market-related benefits as stimuli for full participation in the labor market promotes an unequal distribution of welfare. Labor market participation is still heavily mediated by social class. Thus linking welfare benefits to individual responsibility may give way to a Matthew-effect due to the class effects on labor market participation. Cantillon (2011) confirms this hypothesis in her study on the disappointing poverty rates that exist after the formulation and partial implementation of the Lisbon Strategy. She states that social spending based on the principles of the social investment perspective flows mainly to middle- and higher-income groups and does not adequately reach work-poor households, resulting in unchanged poverty rates. Class differences in the use of childcare also exist. The lower 
classes tend to make less use of childcare services than their counterparts from the higher classes. Increased funding for early childcare education therefore benefits the groups who already make use of these services. This type of funding thus reaches the higher classes more than the lower classes (Van Lanckers \& Ghysels, 2012). Not only does class play a role in the distribution of social risks, but gender also plays an important role. Informal care is usually provided by women (Van den Broek, 2013) who are therefore more susceptible to physical and psychological harm. The shift of responsibilities from state to individual increases the risk of unemployment for women due to injuries sustained during the provision of informal care or reductions in working hours due to informal care obligations which results in less social protection.

Confronting the ideas of the social investment state with the premises of the capability approach leads to important insights. In the social investment paradigm, the well-being of citizens depends on their ability to make decisions that contribute to their well-being and on their willingness to make these decisions. The social investment state offers opportunities to improve capabilities if necessary, along with information and incentives to improve willingness. In the social investment state, the target group of social policies is considered sufficiently willing to take advantage of the opportunities that are offered in the social investment state, and also sufficiently capable of doing this. By willingness, we mean that in the social investment paradigm, citizens are considered to be rational utility-maximizers, motivated to follow courses of action that are in their own self-interest. By ability we mean that the social investment paradigm assumes that citizens are capable of recognizing courses of action that are in their own self-interest. The social investment paradigm produces new social risks if these assumptions are not - or not fully - met in reality. This brings us to a discussion of the social risks of the social investment state in the next section.

\section{A TYPOLOGY OF SOCIAL RISKS IN THE SOCIAL INVESTMENT STATE}

In this section we propose a typology of social investment risks in a welfare state of increasing individual responsibility. We distinguish four groups of social risks in social investment states. These risks are based on the basic paradigms of the social investment state on the one hand, and the assumption of willing and capable individuals on the other. If we combine these basic paradigms with the potential lack of either capabilities or willingness to enter the welfare arrangements of the social investment state, we can distinguish four different social investment risks: 
- Welfare illiteracy;

- The vicious cycle of 'own fault';

- Limited network ties; and

- Limited moral articulation.

In the next paragraphs we elaborate on and empirically illustrate these social investment risks using examples from the country that we know best: the Netherlands. However, in our opinion these risks may apply to countries from any welfare regime that is transforming into a social investment regime.

\section{Welfare illiteracy}

The distribution of social security and welfare is dependent on individual capabilities. This has always been the case, but the role of capabilities is becoming increasingly decisive. As recent research shows, socio-economic and educational differences between individuals even exist in the occurrence, detection and treatment of cancer. The suggestion has been made that differences in health literacy - 'the individual capacity to obtain, process and understand basic health information and services needed to make appropriate decisions' (Aarts, 2012: 237) - plays an important role in acquiring the right kind of health care. Placing the 'literacy' concept in a broader context, we can say that 'welfare literacy' becomes more dominant in the distribution of social security and welfare in the changing social policy context of increasing self-sufficiency and self-control. The move towards personalized social services underpins this assumption.

One example of these personalized services is the personal budget (PGB) that was introduced through the Dutch public health service in 1996. Before that time public health was supply-orientated and mismatches between care recipient and care supplier were common. The personal budget was thus introduced to create a better match between both parties. The personal budget gives people the option to choose their own care supplier, which may be informal or formal, public or private. When someone becomes eligible for funded care under the Exceptional Medical Expenses Act (Awbz) or the Social Support Act (Wmo), the PGH gives them the option to choose care in-kind, or to be given a personal budget for the care they want and need. One of the most important characteristics of this policy measure is that care users have a maximum of freedom to choose how and where they want to spend their budget. In 2003 the 'new style' personal budget was introduced. The biggest and most prominent change was that money is now 
directly transferred to the client without the intervention of a health institution, which was the former protocol. This gives the care user even more freedom than before. They are now responsible for paying their care suppliers (SCP, 2011).

This example illustrates the increase in freedom and personal responsibility to choose a personal path to better welfare, as citizens see fit. The benefit of this kind of policy is that clients can regulate and buy the care and support they need without the interference of a third party. However, regulating one's own care and support without the proper training or education is not the simplest of tasks. The welfare system is complex and changes over time because of innovation or political and economic developments. Several studies have shown that not everybody gets the welfare they are entitled to. The main reasons for citizens not using the welfare measures available to them are that they do not know of these measures, they think they are not eligible for them, or they do not know how to apply (SEO, 2011). This shows that welfare literacy is a big predictor of welfare accumulation. Welfare literacy - the individual capacity to obtain, process and understand welfare information and the services needed to make appropriate decisions - is likely to play a bigger role in the future of the welfare state. In neoliberal or social investment states, where personal responsibility and the freedom to choose one's own welfare suppliers is increasingly emphasized, the amount of knowledge someone possesses about the welfare state will become more important under the influence of both the individualization and the personalization of social policy.

\section{Vicious cycle of 'own fault' ('serves you right')}

A key assumption in the social investment paradigm is that people should take the opportunities that they are offered. It is generally assumed that because of the omnipresence of scientific knowledge people are able to make well-informed choices about matters that affect their future. Following this rationale, it is the 'individual's own fault' when are unemployed because they chose an education or career based on emotional grounds ("because it makes me happy") instead of rational grounds. The social investment risk of the vicious cycle occurs when citizens engage in behavior that is not in their own interest according to the social investment paradigm. The consequences of this 'irresponsible' behavior may involve sanctions in the form of the (partial) denial of services, or incentives aimed at correcting such behavior

One of the most notable examples of this type of social investment risk is the so-called entry-exit paradox (see Kruiter et al., 2008). This paradox implies that 
people are entitled to services or benefits because of the problems they have, but that these problems are also the reason why these services or benefits are denied. For instance, families in debt may be entitled to debt relief services but become ineligible for such services because of new debt they incur during the application of these programs. Other examples are youth with behavioral problems who are removed from behavioral training programs because they do not comply with the rules, and drug addicts who are sent away from the rehab clinic because they use drugs in the rehab facility. In these examples, the observed behavior is interpreted as a lack of willingness on the client side to behave responsibly, even though the causes of such behavior may be situated on a deeper level and may be more related to capabilities than willingness. However, welfare agencies may - and often do - treat behavior from a 'willingness' perspective, creating a vicious cycle in which support for clients - and solutions to their problems remain out of reach.

\section{Limited network ties}

An important element of the Dutch interpretation of the social investment paradigm is reliance of the networks of vulnerable citizens. For instance, the Social Support Act that was implemented by the Dutch Government in 2007 focuses on the promotion of social integration of people with a disability. Local authorities play a key role in this act. The central government sets out the general framework, but it is up to local authorities to decide how they operate within this framework that consists of nine areas in which the local authorities are expected to perform. Area four is of special interest in relation to the new forms of social risk. This area focuses on the support of informal carers and volunteers. Informal carers are typically family, close friends, neighbors and acquaintances. People are expected to make use of existing network ties. Research shows that since $2007 / 2008$ more attention has been placed on formally supporting this group by local authorities than other policy areas within the field of social policy. However, big differences exist between municipalities (SCP, 2010).

The above situation clearly shows that social policy is being increasingly directed towards reliance on informal care. But not everybody has an extensive network on which they can rely in the case of emergencies. Not only does the width of the network matter, but also the composition. As the case illustrates, people with a high demand for care are usually supported by people nearby (socially and geographically) and with whom they have a close connection; i.e., through bonding social capital. In this context it is better to have a large amount 
of bonding social capital than bridging social capital. The case would probably be different in terms of finding a job in a time of harsh labor market conditions.

Not only does the composition of social capital pose a risk, but also the incapability of individuals to manage their own networks in relation to welfare procurement. Because a network is not static but organic, it has to be nurtured and maintained properly to remain in existence. This requires skill in managing social relations and decision-making capabilities based on potential future reciprocity; i.e. social capital revenue (credit slips, Coleman, 1990). But the size of networks is not only dependent on the networking skill of the individual, but also on the potential supply of social relations which can be used to generate social capital. People who are socially excluded are therefore less able to establish networks from which they can gather social capital in relation to welfare procurement because they have less access to these potential social relations (Volker, Flap and Mollenhorst, 2013: 27-38).

\section{Moral Articulation}

As stated before, when people are not capable of caring for themselves, they are expected to rely on their personal networks. We argue that the activation of one's personal network to acquire welfare poses the risk of moral articulation. Asking somebody to provide care or support may create a physical, psychological and social burden on the other. This situation may well challenge the normative beliefs regarding the limits of informal care and create a moral dilemma, making it harder for individuals to ask for help, and in some cases may even prevent people acquiring the support or care they need.

A recent study (Grootegoed \& Dijk, 2012) illustrates this risk in the context of welfare state retrenchment and client autonomy in long-term care. This study was conducted in the Netherlands among disabled and elderly persons who have reduced access to long-term care and are expected to fall back on their family and friends. Through the analysis of 500 telephone interviews and 30 face-to-face interviews the authors concluded that most of the disabled and the elderly do not seek alternatives to the formal care they used to receive. In order to cope with the moral dilemma that is caused by the existing care cap, and not wanting to bother their family members or friends, they use different techniques to manage their moral problem. They mask the need for care in order to not border their relatives with responsibilities, which according the interviewees is 'not their duty'. Or they use hinting techniques and avoid asking directly for support. Both techniques result in less care being received than is actually needed. This problem occurs 
especially with people who relied on formal care in the past. People who used to receive informal care are less affected by retrenchment policies in long-term care.

\section{CONCLUSION AND DISCUSSION}

In this paper we have explored the risks and inequalities that are caused by the transition towards a social investment state. We argue that under the influence of individualization, glocalisation and the increasing emphasis on civil society, individual capabilities and social capital are becoming more important in the procurement of welfare. The risks we distinguish on theoretical grounds are welfare illiteracy, the lack of networks ties, the vicious cycle of 'own fault' and barriers of moral articulation. Any country that moves towards a social investment regime may be confronted with - and should be aware of - these risks. These risks are related to the main assumptions of social investment, namely: the importance of education, equality of opportunities, and the shift in responsibilities from the state to social relations and society. The basis of social investment risk is therefore different in nature than the new social risk defined by Bonoli (2005). New social risks are formed by changing socio-economic relations that result in mismatches with the earlier institutional framework.

This theoretical exploration of the risks of the social investment state offers three important insights for academics and policy-makers. First, the risks that we have identified in this paper are caused by erroneous behavioral assumptions in the social investment paradigm. Specifically, the paradigm might overestimate the capacities and the willingness of citizens to adhere to its basic assumptions. The measures that are taken to correct this behavior also start from the same set of behavioral assumptions. Rather than solving a client's social problems through enabling interventions, these measures lead to the persistence of problems, or even a deterioration in clients' well-being. Therefore, a detailed and systematic assessment of the behavioral assumptions in the social investment paradigm is much needed. This assessment should be aimed specifically at the position of the most vulnerable groups in society.

Second, the social investment paradigm seems to reinforce existing differences between social classes rather than redistribute resources among social classes. Many of the instruments of the social investment state are aimed at citizens that are capable and willing of improving their situations. Most notably, (lower) middle classes seem to benefit from the move towards a social investment paradigm, whereas people in the most vulnerable positions see the gap between them and the middle classes widening (see Cantillon, 2011). 
Third, in this article we have tentatively identified some new risks that may be related to the social investment paradigm. Even though countries with different types of welfare systems have implemented elements of the social investment paradigm (see Hemerijck, 2017), the ways in which the social investment paradigm has been implemented differ significantly. This may lead to different outcomes in terms of the persistence of inequality and the position of vulnerable groups. We therefore make a plea for a systematic comparison of the implementation and outcomes of the shift towards social investment in different welfare regimes. Such a systematic comparison may focus on the benefits of the social investment paradigm, but should not be blind to social investment risks.

\section{REFERENCES}

6, P., (2010) When Forethought and Outturn Part: Types of Unanticipated and Unintended Consequences, in Margetts, H., 6, P. and Hood, C. (eds.), Paradoxes of Modernization: Unintended Consequences of Public Policy Reform, Oxford: Oxford University Press.

Aarts, M. (2012) Socioeconomic determinants of cancer risk, detection, and outcome in the Netherlands since 1990. Doctoral dissertation. Rotterdam: Erasmus University Rotterdam.

Bone, J.D. (2012) The Neoliberal Phoenix: The Big Society or Business as Usual. Sociological Research Online. Vol 17, No. 2, 16

Bonoli, G. (2005). The politics of the new social policies. Providing coverage against new social risks in mature welfare states. Policy and Politics Vol. 33, No. 3, pp. 431-449.

Cantillon, B. (2011). The paradox of the social investment state: growth employment and poverty in the Lisbon era. Journal of European Social Policy. Vol 21, No. 5, pp. 432-449.

Cantillon, B. - Elchardus, M. - Pestieau, P. - Parijs, P van. (eds.) (2003). De Nieuwe Sociale Kwesties. Antwerpen: Garant.

Castles (2004) The Future of the Welfare State: Crisis Myths and Crisis Realities. Oxford: Oxford University Press.

Durkheim, E. (2013 [1897]), Suicide. A Study in Sociology. New York: The Free Press

Elchardus, M. - Marx, I. - Pelleriaux, K. (2003). De nieuwe sociale kwesties: begripsverduidelijking en hypothesevorming, in: Cantillon e.a. (2003)

Friedman, M. (1962) Capitalism and Freedom. Chicago: The University of Chicago Press 
Frey, B. \& Jegen, R. (2001). Motivation Crowding Theory. Journal of Economic Surveys. Vol. 15, No. 5, pp. 589-611.

Gerven, M. van - Ossewaarde, M. (2012). The Welfare State's making of Cosmopolitan Europe. European Societies. Vol. 14, No. 1, pp. 35-55.

Giddens, A. (1998). The Third Way. The Renewal of Social Democracy. Cambridge: Polity Press.

Granovetter, M.S. (1973) The strength of weak ties. American Journal of Sociology. Vol 78, No. 6, pp. 1360-80.

Grootegoed, E. \& Dijk, D van. (2012). The Return of the Family? Welfare State Retrenchment and Client Autonomy in Long-Term care. Journal of Social Policy. Vol. 41, No. 4, pp. 677-694.

Hemerijck, A. (ed.) (2017). The uses of social investment. Oxford: Oxford University Press.

Hoogerwerf, A. (1984) Beleid berust op veronderstellingen: de beleidstheorie, Acta Politica, 4, 493-531.

Jenson, J. (2012). Redesigning citizenship regimes after neoliberalism: moving towards social investment, in

Jenson, J. - Saint-Martin, D. (2003). New Routes to Social Cohesion? Citizenship and the Social Investment State. The Canadian Journal of Sociology. Winter volume.

Jenson, J. and Saint-Martin, D. (2006). Building Blocks for a new social architecture: The LEGO $^{\mathrm{tm}}$ paradigm of an active society. Policy \& Politics. Vol. 34, No. 3, pp. 429-51.

Kääriäinen, J. - Lehtonen, H. (2006). The Variety of Social Capital in Welfare State regimes - A Comparative Study of 21 countries. European Societies. Vol. 8, No. 1, pp. 27-57.

Kazepov, Y. (ed.) (2010), Rescaling social policies: Towards multilevel governance in Europe, Farnham: Ashgate.

Klerk, M. de, Gilsing R. and Timmermans, J. (eds.) (2010). Op weg met de Wmo. Den Haag. Sociaal en Cultureel Planbureau.

Leeuw, F.L. (2003), De beleidstheorie: veronderstellingen achter beleid, in: Hoogerwerf, A. and M. Herweijer (ed.), Overheidsbeleid: een inleiding in de beleidswetenschap, Den Haag: Kluwer.

Leschke, J - Jespen, M (2012) Introduction: Crisis, Policy Responses and Widening Inqualities in the EU. International Labour Review. Vol. 151, No. 4, pp. 289-312.

Mahoney, J. - Thelen, K. (2010) A Gradual Theory of Institutional Change, in Mahoney, J. and Thelen, K. (eds.) Explaining Institutional Change: Ambiguity, Agency, and Power. Cambridge: Cambridge University Press. 
Morel, N. - Palier, B. - Palme, J. (2012). Beyond the welfare state as we knew it? In Morel, N., Palier, B \& Palme, J. (eds). Towards A Social Investment Welfare State? Ideas, Policies and Challenges. Bristol: The Policy Press.

Morel, N. - Palier, B - Palme, J. (2012). Social Investment: a paradigm in search of a new economic model and political mobilization, in Morel, N., Palier, B \& Palme, J. (eds). Towards A Social Investment Welfare State? Ideas, Policies and Challenges. Bristol: The Policy Press.

Nikolai, R. (2012). Towards social investment? Patterns of public policy in OECD world, in Morel, N., Palier, B \& Palme, J. (eds). Towards A Social Investment Welfare State? Ideas, Policies and Challenges. Bristol: The Policy Press.

Oorschot, W. - Arts, W. (2005) The Social Capital of European Welfare States: The Crowding Out Hypothesis Revisited. Journal of European Social Policy. Vol. 15, No. 1, pp. 5-26.

Pfeifer, M. (2009) Public Opinion on State Responsibility for Minimum Income Protection: A Comparison of 14 European Countries. Acta Sociologica. Vol. 52, No. 2, pp. 117-134.

Pierson, P. (1994). Dismantling the Welfare State? Reagan, Thatcher and the Politics of Retrenchment, Cambridge: Cambridge University Press.

Pintelon, O. - Cantillon, B. - Van Den Bosch, K. - Whelan, C.T. (2013) The social stratification of social risks: The relevance of class for social investment strategies. Journal of European Social Policy. Vol. 23, No. 1, pp. 52-67.

Putnam, R.D. (2000). Bowling Alone. The Collapse and Revival of American Community. New York: Touchstone.

Sadiraj, K.- Oudijk, D.- Kempen, H. - Stevens, J. (2011). De opmars van het $P G B$. Den Haag: Sociaal en Cultureel Planbureau.

Schrijvershof, C., Thijs, C., Visscher, K. and Aarts, L. (2008). Eindevluatie IRO. Den Haag: APE.

Sen, A. (2005). Human Rights and Capabilities. Journal of Human Development. Vol. 6, No. 2, pp. 151-166.

Sen, A. (1997) Editorial: Human Capital and Human Capability. World Development. Vol. 25, No. 12, pp. 1959-1961.

Streeck, W - Thelen, K. (2005). Beyond continuity: Institutional Change in Advanced Political Economies. Oxford: Oxford University Press.

Taylor-Gooby, P. (2004) New Risk and Social Change, in Taylor-Gooby, P. Rew Risks, New Welfare. The Transformation of the European Welfare State. Oxford: Oxford University Press

Taylor-Gooby, P. (2008). The new welfare state settlement in Europe. European Societies. Vol 10, pp. 3-24.

Taylor-Gooby, P. (2011) The civil society route to social cohesion. International Journal of Sociology and Social Policy. Vol. 32, No 7-8, pp. 368-385. 
Taylor-Gooby, P. - Stoker, G. (2011). The Coalition Programme: A New Vision for Britain or Politics as Usual? The Political Quarterly.Vol. 82, No. 1, pp. 4-15.

Taylor-Gooby, P. (2013) The Double Crisis of the Welfare State and What We Can Do About It. Hampshire: Palgrave Macmillan Ltd.

Tempelman, K., Houkes, A. and Prins, J. (2011). Niet-gebruik inkomensondersteunende maatregelen. Amsterdam: SEO economisch onderzoek.

Van Lanckers, W. - Ghysels, J. (2012) Who Benefits? The social distribution of subsidized childcare in Sweden and Flanders. Acta Sociologica. Vol. 55, No. 2, pp. 125-142.

Volker, B., Flap, H. - Mollenhorst, G. (2013) Sociale netwerken. Vragen, antwoorden en onderzoek. Groningen: Noordhoff Uitgevers.

Wiggan, J. (2012). Telling stories of 21st century welfare: The UK Coalition government and the neo-liberal discourse of worklessness dependency. Critical Social Policy. Vol 32, No. 3, pp. 383-405. 